\title{
IMPACTOS DO SURTO DE FEBRE AFTOSA DE 2005 SOBRE AS EXPORTAÇÕES DE CARNE BOVINA BRASILEIRA
}

\section{IMPACTS OF THE 2005 FOOT AND MOUTH DISEASE OUTBREAK ON BRAZILIAN BEEF EXPORTS}

\author{
Diana Cortes Carvalho Garcia ${ }^{1,2}$ \\ Claudia Valeria Gonçalves Cordeiro de Sá ${ }^{1,3}$ \\ Concepta Margareth McManus ${ }^{1}$ \\ Cristiano Barros de Melo ${ }^{1}$
}

\author{
${ }^{1}$ Universidade de Brasília (UnB/FAV/DINO), Programa de Pós-graduação em Ciências Animais, Brasília, DF, \\ Brasil. \\ ${ }^{2}$ Ministério da Agricultura, Pecuária e Abastecimento (CASSAO/CGA/DNSF/SRI/MAPA), Brasília, DF, Brasil. \\ ${ }^{3}$ Ministério da Agricultura, Pecuária e Abastecimento (DIPOA/MAPA), Brasília, DF, Brasil. \\ *Autor para correspondência: cristianomelo@unb.br
}

\begin{abstract}
Resumo
A febre aftosa é uma barreira sanitária no comércio internacional e implica elevados investimentos para seu controle e graves prejuízos em casos de surto. Este trabalho investigou os impactos causados pela febre aftosa nas exportações de carne bovina in natura do Brasil após o surto de 2005, além do cumprimento do Princípio da Regionalização do Acordo sobre a Aplicação de Medidas Sanitárias e Fitossanitárias (SPS) pelos países membros da OMC, que compunham a lista dos 10 maiores importadores dessa carne em 2004. Foi realizada análise descritiva das exportações de carne bovina congelada e resfriada (carne bovina in natura), considerando-se os anos de 2004 a 2006, para os 10 maiores importadores desses produtos do Brasil e do mundo em 2004. Verificou-se que o surto não impediu o aumento das exportações de carne bovina in natura do Brasil, mas impactou negativamente as exportações do Mato Grosso do Sul e Paraná. A doença não causou impacto nas exportações para os Estados Unidos, Japão e México. Arábia Saudita, Rússia e Irã não eram Membros da OMC em outubro de 2005 e, portanto, não tinham a obrigação de respeitar o Princípio da Regionalização, ainda que a Rússia o tenha feito. Dentre os demais grandes importadores de 2004, os Países Baixos, Egito, Itália, Reino Unido, França, Alemanha e Espanha respeitaram o Princípio da Regionalização do Acordo SPS. O Chile não respeitou o Princípio da Regionalização e a ocorrência da doença fechou aquele mercado à carne bovina brasileira in natura.
\end{abstract}

Palavras-chave: Acordo SPS; agronegócio; diplomacia; doença; barreira sanitária.

\begin{abstract}
Foot and Mouth Disease (FMD) can lead to sanitary barriers to international trade and involves high investments for control and great losses in the event of an outbreak. This study investigated the impacts caused by FMD on the exports of fresh beef from Brazil after the 2005 outbreak and the observance of the regionalization principle of the Agreement on the Application of Sanitary and Phytosanitary Measures (SPS) by countries member of the WTO that were listed as the top 10 beef importing countries in 2004. The FMD outbreak that began in 2005 did not limit the increase in exports of fresh beef from Brazil, but impacted negatively on exports from Mato Grosso do Sul and Paraná States. The disease did not impact exports to the United States, Japan or Mexico, since these markets were
\end{abstract}


closed to Brazil. Saudi Arabia, Russia and Iran were not members of the WTO in October 2005 and therefore had no obligation to respect the principle of regionalization, though Russia respected it. Among the other major importers of 2004, the Netherlands, Egypt, Italy, United Kingdom, France, Germany and Spain respected the principle of regionalization of the SPS Agreement. Chile did not respect the principle and the occurrence of the disease closed the market to Brazilian fresh beef.

Keywords: Disease; diplomacy; international trade; sanitary barrier; SPS agreement.

Recebido em: 21 agosto 2013

Aceito em: 01 junho 2015

\section{Introdução}

A febre aftosa é uma doença de notificação obrigatória que acomete animais biungulados, implica importantes perdas econômicas e é considerada uma das doenças de rebanho mais contagiosas ${ }^{(1,2)}$. Por tais características, trata-se de uma importante barreira sanitária no comércio internacional de produtos de origem animal. Esta doença pode ser disseminada por animais vacinados ou por seus produtos e, por isso, o comércio internacional dessas commodities é limitado em diversos graus. Países importadores podem proibir tal comércio ou permiti-lo apenas mediante a aplicação de rígidas medidas sanitárias. Devido às grandes dificuldades para o seu efetivo controle e o seu impacto econômico, é considerada a doença infecciosa mais importante do mundo ${ }^{(3,4)}$.

O surgimento da febre aftosa nos rebanhos de um país causa prejuízos financeiros locais para a população, com o sacrifício sanitário de animais, prejuízos comerciais pelas barreiras sanitárias e os seus custos decorrentes do alto poder infectante do vírus ${ }^{(5,6)}$. A febre aftosa se espalhou da China para a Mongólia, Coréia do Sul e Japão em 2010. Os custos de controle e as perdas diretas para a agricultura foram estimados em 2,8 bilhões de dólares na Coréia do Sul, que resultou na elevação do preço da carne suína no país e aumento das importações ${ }^{(7)}$. Em abril de 2010, o Japão notificou a ocorrência de febre aftosa na província de Miyazaki, que é uma das províncias com maior número de cabeças de gado e fazendas de suínos no Japão. Epidemias de febre aftosa nesta área causaram graves danos à indústria pecuária local e às indústrias relacionadas. Durante essa epidemia, foram detectadas 292 propriedades infectadas. Cerca de 37 mil bovinos e 174 mil suínos foram abatidos nessas fazendas, atingindo um total de 290 mil animais susceptíveis abatidos durante a epidemia ${ }^{(6)}$. No Brasil, em 2005, o surto ocorreu em uma região exportadora, enquanto no Japão, ocorreu em uma das principais áreas de produção embora não exportadora de carne bovina. Ainda assim, os custos totais de controle foram estimados em US\$ 550 milhões.

Por um único suíno exportado para Taiwan a partir de Hong Kong em 1997, a doença propagou-se por toda Taiwan em seis semanas, onde foram abatidos mais de oito milhões de suínos e US\$ 19 bilhões foram gastos, sendo US \$ 4 bilhões para erradicar a doença e outros US\$ 15 bilhões em perdas comerciais $^{(8)}$. Para a Federação Internacional para a Saúde Animal ${ }^{(7)}$, esses números foram menores, constituindo-se de US\$ 6,6 bilhões de custo total e quatro milhões de animais abatidos, o que mesmo assim representou um impacto de grandes proporções.

O surto de 2001 de febre aftosa na Europa, embora concentrado na Grã-Bretanha, espalhou-se para a França, a República da Irlanda, Países Baixos e Irlanda do Norte ${ }^{(5)}$. Após a epidemia, agricultores e outras pessoas afetadas pela crise tiveram a vida acompanhada por sofrimento, sentimentos de perda, medo de um novo desastre, perda de confiança nas autoridades e no sistema de controle ${ }^{(7)}$. Para conter a epidemia de febre aftosa que se alastrou pelo Reino Unido naquele ano, o país dispensou mais de US\$ 11 bilhões e sacrificou mais de seis milhões de animais ao longo de sete meses e meio.

As estimativas dos custos totais do surto variam significativamente. Um estudo de 2002 do "National Audit Office" do Reino Unido estimou os custos diretos em US\$ 4,3 bilhões e os custos indiretos em US\$ 7,2 bilhões. Mas esses não foram os únicos gastos decorrentes do surto. Devido à capacidade de o vírus ser transmitido por objetos inanimados, como roupas ou rodas de veículos, o público foi desencorajado a visitar o campo durante a epidemia. Como resultado, as receitas do turismo rural 
caíram 14,5\% em 2001 em comparação com o mesmo período do ano anterior, chegando a uma perda para o setor de $£ 179$ milhões por semana ou $£ 7,7$ bilhões ao longo do ano ${ }^{(9)}$.

A demora no diagnóstico primário no foco inglês foi determinante para a evolução da doença e elevação dos custos. O papel de possíveis fatores na facilitação da entrada do vírus tem sido discutido, como a redução significativa no número de pesquisadores em febre aftosa naquele país desde 1981; a redução das equipes veterinárias oficiais - que diminuiu a inspeção de rotina e vigilância; e a decisão dos países ocidentais da UE de não mais vacinarem seu gado contra a febre aftosa ${ }^{(10)}$. Ainda no ano de 2001 o Uruguai foi afetado pela mesma doença. Vinte mil animais foram abatidos e US\$ 730 milhões foram gastos para conter a doença ${ }^{(7)}$. Em 2002, o mero rumor de febre aftosa no Estado de Kansas, Estados Unidos, resultou em um custo de US\$ 50 milhões ${ }^{(8)}$.

A importância do mercado pecuário para a economia brasileira somada aos elevados custos e impactos decorrentes da contenção de um surto de febre aftosa justificam todo o esforço envidado pelo governo e pela cadeia pecuária na manutenção de um serviço de defesa sanitária forte e eficiente com vistas a manter a febre aftosa fora das fronteiras nacionais. Entretanto, a carne bovina pode ser exportada como um produto seguro mesmo quando proveniente de países ou zonas que não estão livres de febre aftosa, desde que sejam tomadas precauções para reduzir a probabilidade de abate de animais infectados e que se cumpram os procedimentos da Organização Mundial de Saúde Animal (OIE) durante a preparação da mercadoria, como a vigência de um programa oficial de controle da febre aftosa com vacinação sistemática obrigatória do gado e algumas condições mais específicas ${ }^{(11)}$.

Em 2005, a febre aftosa foi detectada no Mato Grosso do Sul e no Paraná, Estados do Brasil fortemente envolvidos na produção e exportação de carne bovina. O surto iniciado em 2005 levou vários países a proibirem a importação de carne brasileira, incluindo a Rússia, principal mercado do Brasil na época. Ocorreu uma queda no faturamento das vendas nacionais e internacionais e, posteriormente, uma queda no preço da carne no mercado interno devido ao excesso de oferta. Em decorrência, pecuaristas deixaram o setor, o que também ocasionou queda na produção de bezerros nos anos de 2006 e 2007 e o mercado só se recuperou a partir de $2008^{(7)}$.

Este trabalho objetivou investigar os impactos imediatos causados pela febre aftosa às exportações de carne bovina in natura do Brasil, e dos estados do Mato Grosso do Sul e do Paraná, após o surto de 2005 e o cumprimento do Princípio da Regionalização do Acordo sobre a Aplicação de Medidas Sanitárias e Fitossanitárias (SPS) pelos países membros da Organização Mundial do Comércio (OMC) que compunham a lista dos 10 maiores importadores dessa carne do Brasil e do mundo de 2004 a 2006.

\section{Material e Métodos}

Foram pesquisadas normativas e relatórios oficiais referentes ao tema, arquivos públicos sobre a negociação agropecuária internacional brasileira disponibilizados pela Secretaria de Relações Internacionais do Agronegócio (SRI/MAPA), estatísticas brasileiras oficiais de exportação de carne bovina do Brasil para o mundo do Sistema de Estatísticas de Comércio Exterior do Agronegócio Brasileiro - AGROSTAT ${ }^{(12)}$, e os dados do sistema Trademap do "International Trade Centre"(13) sobre as importações mundiais de carne bovina no período proposto.

Foi realizada análise descritiva das exportações de carne bovina congelada e resfriada, que o Ministério da Agricultura, Pecuária e Abastecimento (MAPA) classifica como carne bovina in natura, considerando-se os anos de 2004, 2005 e 2006, para os 10 maiores importadores desses produtos do Brasil e do mundo em 2004(14) e foi verificado se o Princípio da Regionalização do Acordo SPS foi respeitado pelos países membros da (OMC), quando da ocorrência do surto de febre aftosa no Brasil, iniciado em 2005 e encerrado em 2006. Para a análise qualitativa dos dados, comparou-se o volume exportado pelo Brasil no ano anterior e posterior ao início do surto de febre aftosa de 2005, destinado aos 10 maiores importadores de carne bovina in natura do Brasil e aos 10 maiores importadores do mundo, de modo que foi avaliada a redução, manutenção ou aumento das exportações no período 
apesar da ocorrência da febre aftosa, com o intuito de investigar os impactos causados pela doença às exportações de carne bovina in natura do Brasil e dos Estados do Mato Grosso do Sul e do Paraná. Dentre esses parceiros comerciais, foi avaliado se os que eram Membros da OMC à época cumpriram com o Princípio da Regionalização do Acordo SPS.

\section{Resultados e Discussão}

Com a notificação oficial da ocorrência de um foco de febre aftosa no Mato Grosso do Sul, feita à OIE em 9 de outubro de $2005^{(11)}$, os parceiros comerciais do Brasil começaram a se pronunciar quanto a restrições às importações de origem brasileira ${ }^{(14)}$. As atualizações da lista dos países embargantes eram extensas e divulgadas periodicamente pelo MAPA em seu sítio eletrônico, porém não eram exaustivas devido às constantes alterações de cenário. Foram divulgados pelo MAPA 58 países que impuseram oficialmente restrições ao Brasil ${ }^{(14)}$.

No somatório das participações individuais, os países que impuseram oficialmente qualquer restrição ao Brasil devido à febre aftosa, por menor que fosse, representavam $86,74 \%$ do mercado consumidor internacional da carne brasileira. Isso demonstrou a preocupação do mundo com o controle da febre aftosa, já que apenas 13,26\% dos países clientes do Brasil não comunicaram algum tipo de embargo posterior ao surto, o que não impediu que o fizessem de maneira não oficial ${ }^{(12-14)}$.

Os 10 principais importadores de carne bovina in natura do mundo eram, no ano de 2004, em ordem decrescente de valor importado no ano, os Estados Unidos, Itália, Japão, Reino Unido, França, Países Baixos, Alemanha, México, Rússia e Espanha. À época, os 10 principais mercados importadores de carne bovina in natura do Brasil eram, em ordem decrescente de valor importado no ano, Rússia, Países Baixos, Chile, Egito, Itália, Reino Unido, Irã, Alemanha, Espanha e Arábia Saudita. Esses países respondiam por $72 \%$ das importações desse produto brasileiro. Os demais $28 \%$ englobavam 41 países, todos com menos de 4\% de participação individual nesse mercado ${ }^{(13)}$. Dentre esses 10 grandes importadores mundiais, apenas os Estados Unidos, Japão e México não consumiam a carne bovina in natura do Brasil. Assim, a pecuária bovina brasileira já havia conquistado parcela importante no cenário internacional em questão, e trabalhava para abrir novos mercados quando foi surpreendida pelo surto de febre aftosa dentro de sua área livre no ano de $2005^{(15)}$.

Ao se excluirem as importações do Chile, da Rússia e dos 25 países que compunham a União Europeia (UE) em 2004 (UE-25), da lista dos 58 embargantes, os demais 31 países representaram, coletivamente, $25 \%$ do mercado destino da carne bovina in natura brasileira, ou seja, individualmente, eles contribuíam com uma parcela bastante reduzida no valor exportado pelo Brasil ${ }^{(12-14)}$.

De todos os países que comunicaram alguma restrição pós-surto, apenas África do Sul, Belarus, Chile, Indonésia, Marrocos, Namíbia, Tailândia, Uruguai e Venezuela impuseram extensos embargos ao território brasileiro em decorrência da febre aftosa e desrespeitaram o Princípio da Regionalização da OMC, uma vez que estenderam suas restrições à importação de carne bovina de área ainda considerada livre pela $\mathrm{OIE}^{(14)}$. Desses, apenas Belarus não era membro da $\mathrm{OMC}$ e, portanto, não estava obrigado a cumprir o Acordo SPS na íntegra ${ }^{(16)}$. À exceção do Chile, esses demais países eram clientes de menor peso no mercado exportador brasileiro, sendo que outro exemplo disso foi a Venezuela, que participava de tão somente $1,10 \%$ das exportações de carne bovina in natura do Brasil em 2004. Ainda, Belarus, Marrocos, Namíbia e Tailândia já não importavam qualquer quantidade desse produto brasileiro desde 2004, ou seja, as restrições impostas por eles, embora rígidas, não causaram qualquer impacto ao comércio pré-existente com o Brasil ${ }^{(12-14)}$.

Por sua vez, o Chile, importante parceiro comercial do Brasil, ao proibir a importação de carne bovina in natura de todo o país, reduziu drasticamente sua participação no mercado brasileiro de 10,13\% em 2004, para $5,79 \%$ e $0,59 \%$ em 2005 e $2006^{(14)}$, respectivamente. De terceiro maior importador dessa carne brasileira em 2004, passou para o $6^{\circ}$ lugar em 2005 e sequer figurou na lista dos 10 maiores importadores de $2006^{(13)}$. Embora o Chile tenha sido o mercado que mais negativamente foi impactado pela febre aftosa, o Irã também apresentou forte queda em 2005 (de 5,20\% de participação 
no mercado brasileiro em 2004 para 0,50\% em 2005 e 3,40\% em 2006, quando voltou a subir).

Os países que oficializaram suas restrições, Arábia Saudita e Irã, não são mencionados como embargantes, ou seja, eles faziam parte da lista dos 10 maiores importadores, correspondiam aos $13,26 \%$ que não emitiram nota de embargo, mas, mesmo assim, reduziram suas compras no período mais crítico ${ }^{(14)}$. É possível que a medida de não importar carne bovina in natura do Brasil tenha partido de uma decisão discricionária do próprio setor privado importador ou, ainda, que tenha sido resultado de um embargo silencioso por parte desses países. Nesse segundo caso, seria necessário averiguar junto ao setor privado exportador se houve, no período, retenção de carga ou rechaço nos portos de destino, o que caracterizaria uma medida governamental e não uma mera opção dos importadores.

Os Países Baixos, Alemanha, Espanha e Arábia Saudita - respectivamente o $2^{\circ}, 8^{\circ}, 9^{\circ}$ e $10^{\circ}$ maiores compradores desse produto brasileiro em 2004 - reduziram sua participação no mercado brasileiro nos anos de 2005 e 2006, comparativamente a $2004^{(12)}$, embora todos os oito maiores importadores do Brasil que chegaram a emitir alguma nota de embargo importaram um valor superior em carne bovina in natura brasileira em 2006 do que o faziam em 2004, mostrando que o surto de febre aftosa não foi fator impeditivo para a realização de comércio com esses países. Embora tenham sido vários os embargos ao Brasil, os países que o fizeram de maneira indiscriminada tinham menor participação no mercado brasileiro, gerando menor impacto no total exportado.

Quando foram consideradas as exportações do Brasil como um todo, a presença da febre aftosa no país em 2005 não impediu exportação de ainda mais carne bovina in natura em 2005 e 2006, comparativamente a 2004. Os grandes importadores que já compravam do Brasil respeitaram o Princípio da Regionalização, confiando no sistema de saúde pública e veterinária do país e na sua capacidade de manter o foco restrito aos locais de origem, o que foi demonstrado pelo aumento nas importações do produto brasileiro durante um período crítico para o setor brasileiro.

No período de 2000 a 2005 houve uma mudança estrutural em relação à participação dos diversos países nos destinos das exportações do agronegócio nacional ${ }^{(17)}$. O número de mercados subiu de 182 países em 2000 para 214 em 2005. Havia no ano de 2000 uma concentração de 18,10\% do comércio do agronegócio com os Estados Unidos, entretanto, em cinco anos, esse valor declinou para 13,7\%. No mesmo período, países como a China e a Rússia passaram de 2,82\% e 2,18\% para 7,08\% e 6,23\%, respectivamente. A maior parte dos países europeus também teve a sua participação reduzida, como, por exemplo, a Alemanha (de 6,08\% para 4,25\%) e a Bélgica (de 5,20\% para 2,78\%). Quando se analisou conjuntamente a UE, verificou-se que a participação do bloco caiu de cerca de $40 \%$ para $32 \%$ do total das exportações brasileiras do agronegócio. Apesar do surto de febre aftosa ocorrido no país em 2005, o perfil comercial encontrado por Machado ${ }^{(17)}$ no agronegócio se reproduziu em 2006 no que se relacionava à carne bovina in natura brasileira. De uma maneira geral, percebeu-se uma descentralização de clientes e um aumento no volume e valor das exportações.

Dos maiores importadores mundiais de carne bovina in natura, Estados Unidos, Japão e México não foram influenciados pelo surto de febre aftosa no Brasil, uma vez que seus mercados ainda eram (e são) fechados à carne bovina in natura brasileira. Entretanto, sua ocorrência pode ter procrastinado o processo de abertura desses mercados, uma vez que todos possuem análise de risco para exportação da carne bovina in natura do Brasil em curso.

Quanto à UE, houve redução na participação no mercado exportador brasileiro, tendência que foi observada mesmo antes da ocorrência da febre aftosa ${ }^{(17)}$. Embora sob restrição comercial, o Brasil aumentou suas exportações, o que leva a crer que o impacto da febre aftosa junto à UE foi mais no sentido de restringir o crescimento do comércio com o Brasil em um primeiro momento, do que inviabilizá-lo ou mesmo reduzi-lo. A UE em 2004 ainda era formada por 25 países, conhecidos pela sigla UE-25(18). Naquele ano, ela importou oito bilhões de dólares em carne bovina in natura do mundo. Em 2004, 2005 e 2006, o Brasil foi o quinto maior fornecedor de carne bovina in natura para o Bloco Europeu e, desconsiderando-se como exportadores os próprios países membros, o Brasil foi o maior fornecedor desse produto para a EU em 2004(13).

Dos 10 maiores importadores de carne bovina in natura do mundo em 2004, seis eram membros da UE: Itália ( $2^{\circ}$ maior importador), Reino Unido $\left(4^{\circ}\right)$, França $\left(5^{\circ}\right)$, Países Baixos $\left(6^{\circ}\right)$, Alemanha $\left(7^{\circ}\right)$ e 
Espanha $\left(10^{\circ}\right)$. O Brasil exportou para esses seis países nos anos de 2004, 2005 e 2006, apresentando queda no valor exportado para a Alemanha, Espanha e Países Baixos no ano de 2005, em relação a $2004(-5,56 \%,-25,98 \% \text { e }-10,47 \% \text {, respectivamente })^{(13)}$. A Espanha também apresentou queda no valor importado do Brasil em 2006, enquanto todos os demais mercados mencionados se recuperaram nesse ano ${ }^{(12)}$. Assim, mesmo com a notificação de febre aftosa em 2005, as exportações brasileiras de carne bovina in natura para a França, Itália e Reino Unido foram crescentes nos anos de 2005 e 2006 em relação a $2004^{(12-14)}$, o que foi de grande importância para o setor exportador brasileiro, considerando a importância que a EU representava para o agronegócio do Brasil à época - sozinho, o Bloco importou quase $40 \%$ de toda a carne bovina in natura brasileira em $2004^{(12)}$ e quase 1 bilhão de dólares em $2006^{(13)}$.

Apesar das quedas no comércio com alguns países europeus com menor participação no mercado exportador brasileiro e, principalmente, com os Países Baixos, Alemanha e Espanha, quando se trata da coletividade das exportações da carne bovina in natura brasileira para a UE, o Brasil apresentou crescimento no valor exportado de $4,88 \%$ e $21,53 \%$ em 2005 e 2006, respectivamente, comparandose aos anos imediatamente anteriores.

As medidas sanitárias e fitossanitárias eram o impedimento mais importante para as exportações agrícolas e alimentares para a EU ${ }^{(19)}$. O fato de a UE-25 ter respeitado o Princípio da Regionalização do Acordo SPS como cabe aos Membros da $\mathrm{OMC}^{(16)}$, confiado no sistema de saúde pública e veterinária do Brasil e na sua capacidade de manter o foco restrito aos locais de origem ao embargar as importações de carne bovina brasileira somente dos Estados do Mato Grosso do Sul, Paraná e São Paulo ${ }^{(14)}$ pode ter sido primordial para permitir o crescimento das exportações para a UE.

Os Estados Unidos, membros da OMC ${ }^{(16)}$, importaram do mundo, em 2004, 3,4 bilhões de dólares em carne bovina in natura, o que lhe garantiu o título de maior importador desse produto naquele ano - e mesmo nos dois subsequentes, ainda que também figurassem como grande exportador desse mesmo item $^{(13)}$. Seus cinco principais fornecedores em 2004 foram Canadá, Austrália, Nova Zelândia, Uruguai e México, respectivamente, com 34,6\%, 34,1\%, 18,6\%, 9,2\% e 1,7\% de participação no mercado importador estadunidense ${ }^{(13)}$. À exceção do Uruguai, que era o único país livre de febre aftosa com vacinação, seus outros quatro grandes fornecedores são livres da doença e não vacinam seus animais contra a mesma ${ }^{(11)}$.

Os Estados Unidos não importavam carne bovina in natura do Brasil mesmo antes do surto de 2005, uma vez que a análise de risco que viabilizaria a importação desse produto ainda não havia sido concluída. Embora aquele país cumprisse com as recomendações emanadas pelos Organismos Internacionais de Referência (OIE, Convenção Internacional de Proteção Fitossanitária e Codex Alimentarius), ao elaborar sua análise de risco para esclarecer os requisitos sanitários e fitossanitários de importação de produtos de origem animal e vegetal, ele também considerava parâmetros adicionais que tornavam o processo mais demorado e burocrático que nos demais países, como a destinação do produto importado, sua origem, quantidade, se há equivalência entre os sistemas de saúde pública veterinária e saúde animal dos Estados Unidos e do país exportador, além de particularidades que extrapolam a questão técnico-científica, como a análise de impacto econômico da adoção da medida para pequenos produtores locais ${ }^{(20)}$.

Durante a última década, houve crescente preocupação nos Estados Unidos com eventos que afetam a biossegurança agrícola nacional, seus canais de marketing e seu comércio internacional. Tal tomada de consciência foi consequência natural do atentado terrorista em Nova Iorque em 11 de Setembro de 2001, somado ao foco no agroterrorismo vivenciado pelo país durante a primeira parte da década de $1990^{(21)}$. O "Congress Research Service" daquele país considerou agroterrorismo como um subconjunto do bioterrorismo, definido como a introdução deliberada de doença animal ou vegetal para afetar a pecuária ou o abastecimento de alimentos, gerando medo, causando perdas econômicas e/ou minando a estabilidade ${ }^{(8)}$. A aprovação da Lei de Bioterrorismo nos Estados Unidos, em 2002, alterou a forma como os produtos agrícolas e alimentares são transportados, importados e exportados ${ }^{(21)}$.

A entrada da febre aftosa na região centro-atlântica dos Estados Unidos poderia acarretar perdas para a economia dos EUA de cerca de US\$ 11,7 bilhões, com efeito cascata no restante do mundo de US\$ 
14,1 bilhões. Impactos tão significativos e um histórico de bioterrorismo confirmado refletem na dura política comercial do país, que ainda não concluiu a análise de risco da carne bovina in natura brasileira e mantém seu mercado fechado a tal produto do Brasil ${ }^{(21)}$. Por não haver exportação da carne bovina in natura do Brasil para os Estados Unidos, a ocorrência da febre aftosa não poderia fechar um mercado que sequer se abriu. Entretanto, sua ocorrência pode ter procrastinado o processo de abertura daquele mercado, uma vez que ainda em 2012 se encontrava em curso a análise de risco para exportação da carne bovina in natura do Brasil aos Estados Unidos.

O Japão importou do mundo 1,8 bilhões de dólares em carne bovina in natura, no ano de 2004, tendo sido o terceiro maior importador mundial desse produto naquele ano ${ }^{(13)}$. Seu principal fornecedor era a Austrália, seguida à distância por Nova Zelândia, México, Estados Unidos e Chile com, respectivamente, $91,9 \%, 6,8 \%, 0,7 \%, 9,2 \%$ e $1,7 \%$ de participação no mercado importador japonês. Todos esses países são livres de febre aftosa sem vacinação ${ }^{(11)}$.

A maior questão sanitária entre Brasil e Japão é relativa ao comércio de carnes: o mercado japonês é fechado à carne bovina brasileira em decorrência da vacinação contra febre aftosa praticada no Brasil, uma vez que a legislação japonesa permite a importação somente de países ou zonas reconhecidos internacionalmente pela OIE como livres da doença sem vacinação ${ }^{(20)}$. Considerando que somente o Estado de Santa Catarina é livre de febre aftosa sem vacinação no Brasil ${ }^{(11)}$, as negociações entre os dois países têm se baseado na solicitação de exportação de carnes brasileiras apenas desse Estado para o Japão ${ }^{(20)}$. Ainda que o mercado consumidor de carne bovina do Japão fosse aberto aos bovinos sem vacinação contra aftosa do Brasil, Santa Catarina não seria capaz de abastecer o mercado, uma vez que o Estado é focado na exportação de carne de suínos e aves. Em 2004, 2005 e 2006, Santa Catarina foi responsável por tão somente $0,27 \%, 0,56 \%$ e $0,17 \%$, respectivamente, das exportações de carne bovina in natura do Brasil ${ }^{(12)}$.

Assim como no caso dos Estados Unidos, não se pode afirmar que o surto de febre aftosa de 2005 tenha impactado o comércio de carne bovina in natura entre o Brasil e Japão, uma vez que se trata de mercado fechado e, portanto, de comércio inexistente. Embora o Japão reconheça o Princípio da Regionalização do Acordo SPS, a prática da vacinação no Brasil inviabiliza as exportações do país, à exceção de Santa Catarina, que muito pouco representa do mercado exportador brasileiro de carne bovina. Sem que haja uma expansão da zona livre de febre aftosa sem vacinação ou alteração da legislação japonesa, o mercado japonês permanecerá fechado à carne bovina in natura brasileira.

A indústria de produtos cárneos e processados não é tão bem desenvolvida no Oriente quanto no Ocidente devido às questões históricas, geográficas, religiosas e culturais. Tradicionalmente, a dieta oriental baseia-se em cereais e vegetais, com consumo limitado de carnes e derivados. O crescimento econômico recente, a introdução de alimentos ocidentais e o desenvolvimento de novos produtos cárneos industrializados com base em receitas orientais ocidentalizadas mudaram os hábitos alimentares no Oriente ${ }^{(22)}$. Por esses motivos, foi previsto um grande desenvolvimento na indústria de cárneos na região, o que torna o mercado japonês promissor aos olhos do agronegócio brasileiro e digno de investimento, ainda que atualmente fechado à carne bovina brasileira.

O México importou do mundo quase 720 milhões de dólares em carne bovina in natura no ano de 2004, tendo sido o sétimo maior importador desse produto naquele ano ${ }^{(13)}$. Cerca de $58 \%$ de suas importações vieram dos Estados Unidos, seu principal parceiro comercial, seguido do Canadá com $36,5 \%$, Nova Zelândia (1,6\%), Chile $(1,4 \%$ ) e Austrália (1,1\%). Todos esses países são livres de febre aftosa sem vacinação ${ }^{(11)}$. A legislação mexicana não reconhece como livres de doenças países ou áreas que praticam vacinação, embora, de forma contraditória, o México importe carne bovina in natura do Uruguai, único país considerado livre de febre aftosa com vacinação pela $\mathrm{OIE}^{(11,13)}$. As posições mexicanas frente a questões de ordem sanitária e fitossanitária são próximas às dos países vizinhos, com os quais possui acordos de comércio que podem influenciar o tratamento dado ao Brasil ${ }^{(20)}$.

Da mesma forma que nos casos dos Estados Unidos e do Japão, o surto de febre aftosa em 2005 não causou impactos no comércio entre Brasil e México, uma vez que aquele país já não comprava carne brasileira por ser oriunda de animais vacinados contra febre aftosa. Está em andamento análise de 
risco para exportação desse produto oriundo de Santa Catarina ${ }^{(20)}$, mas enquanto não houver expansão da área livre de febre aftosa sem vacinação, por mais que o México habilite Santa Catarina a exportar carne bovina àquele país, o Estado não será capaz de abastecê-lo, visto que não é exportador desse produto $^{(12)}$.

Gestões na esfera multilateral, como uma consulta para abertura de painel na OMC, podem ser um caminho para levar o México a dar ao Brasil o mesmo tratamento dispensado ao Uruguai, país livre de febre aftosa com vacinação habilitado a exportar carne bovina in natura ao México. Para tanto, é necessário que o setor privado se manifeste favorável ao pleito, uma vez que a abertura de painel abarca custos elevados e o benefício a ser atingido precisa ser devidamente medido por aquele setor a fim de que se justifiquem os gastos decorrentes.

Já os comércio com a Rússia, embora o país tenha imposto restrições às importações de carne bovina de alguns Estados brasileiros, não foi impactado pela entrada da doença, uma vez que as importações de carne brasileira foram muito maiores no período do surto que antes dele. Em 2004, a Rússia importou do mundo quase 688 milhões de dólares em carne bovina in natura, tendo sido o nono maior importador desse produto naquele ano ${ }^{(13)}$. Suas importações mundiais mais que dobraram até 2006, aumentando $38 \%$ de 2004 para 2005 e $68 \%$ de 2005 para 2006. Dessas importações, $24,9 \%$ eram produtos brasileiros em 2004, 39,5\% em 2005 e 36,8\% em 2006. Os principais fornecedores para a Rússia em 2004, além do Brasil, foram a Ucrânia, Argentina, Alemanha e Irlanda, com 23,7\%, 15\%, $8,5 \%$ e $6,5 \%$, respectivamente, de participação no mercado russo ${ }^{(13)}$.

Durante o surto de febre aftosa, a Rússia foi o maior importador de carne bovina in natura do Brasil, possuindo, sozinha, $12,18 \%$ de participação nesse mercado brasileiro em 2004, 22,95\% em 2005 e $23,71 \%$ em $2006^{(12)}$. Em 2005, o Brasil exportou mais de meio milhão de dólares desse produto para a Rússia, o que representou um aumento de $132,23 \%$ nas importações de 2005 , comparativamente a $2004^{(12-14)}$. Assim, embora a Rússia tenha imposto restrições às importações de carne bovina do Brasil, a entrada da doença não impactou o comércio com aquele país em termos de nação ${ }^{(20)}$, ao contrário, as exportações brasileiras deram um grande salto no período já que a Federação Russa, ao estabelecer as áreas de embargo ao Brasil, considerou válidas as garantias dadas pelos Sistemas Brasileiros de Saúde Pública Veterinária e de Saúde Animal e na consequente capacidade do país em manter o foco da doença restrito aos locais de origem. Mato Grosso do Sul, Paraná, Santa Catarina e Minas Gerais foram os estados que foram proibidos de exportar carne bovina à Rússia ${ }^{(14)} \mathrm{e}$, até abril de 2007, o Rio Grande do Sul, Goiás, Mato Grosso, Tocantins, Rondônia e São Paulo eram os estados habilitados a exportar carne bovina in natura àquele país ${ }^{(20)}$.

O comércio de carnes com a Rússia apresentava grande instabilidade devido à adoção frequente de medidas sanitárias. As medidas apresentavam os mais diversos níveis de correlação com as normas internacionais: podiam ser adotados integralmente os critérios definidos pela OIE ou a medida ser completamente vinculada a alguma legislação russa sem qualquer embasamento científico. Em 2006, o Governo da Rússia baixou a Decisão No 159, de 24/03/2006 que possibilitou maior previsibilidade na adoção de medidas SPS pelo Governo Russo e adequação às normas internacionais, já que regia que a entrada de animais vivos e produtos animais no espaço alfandegário russo passaria a ser regulada pelas normativas veterinárias vigentes da Federação da Rússia que não contradiziam o Código Sanitário para os Animais Terrestres da OIE e que, no caso em que os requerimentos russos contradissessem os regulamentos veterinários da $\mathrm{OMC}$, se aplicariam as normativas do referido Código ${ }^{(23)}$.

Ainda que não se tenha observado queda nas exportações de carne bovina in natura do Brasil para o mundo no período pós-aftosa de 2005, o que indica que o país atingiu um grau de maturidade em seu controle sanitário que satisfez as demandas internacionais dos maiores importadores desse produto no mundo, o setor privado e os Estados com presença da doença não passaram incólumes à febre aftosa. Ao se analisarem os componentes do PIB da pecuária brasileira de 1994 a 2011, observou-se que todo o setor pecuário - insumos, pecuária, indústria e distribuição - foi negativa e homogeneamente impactado no período entre 2004 a 2006. O evento sanitário de maior repercussão negativa na pecuária, na ocasião, foi a ocorrência da febre aftosa no Paraná e Mato Grosso do Sul. Apesar dos bons resultados obtidos pelo Brasil nas exportações de carne bovina in natura em 2005 e 2006, não 
há que se falar de ausência de impacto da febre aftosa para o setor pecuarista brasileiro frente à queda nos componentes do PIB da pecuária brasileira: o setor privado absorveu prejuízos decorrentes dos embargos, embora não se possa responsabilizá-los exclusivamente pela queda na cadeia, uma vez que diversos outros fatores como variação cambial, poderiam influenciar esses dados.

A confirmação do primeiro foco de aftosa em outubro de 2005, seguida pelos embargos à carne brasileira, teve forte impacto no mercado interno ${ }^{(24)}$. Entre os dias 10 e 28 de outubro daquele ano, o Indicador ESALQ/BM\&F do boi gordo à vista recuou $8 \%$, enquanto que na semana imediatamente anterior, esse mesmo Indicador tinha registrado alta de 9\%. Ainda no ano de 2005, os preços tiveram um comportamento bastante atípico, com movimentos diferentes dos observados nos três anos anteriores, incluindo desvalorizações na entressafra ${ }^{(24)}$. Houve redução nas margens de lucro dos pecuaristas e também da indústria. Em referência aos preços da arroba de carne bovina de 2003 a 2006, o Indicador ESALQ/BM\&F do boi gordo à vista saiu de seu nível mais baixo em janeiro de 2006 para atingir, em setembro do mesmo ano, os patamares nominais equivalentes aos de 2004 - os valores mais altos identificados naquele período de quatro anos ${ }^{(25)}$. Foram necessários 11 meses para o valor de mercado recuperar-se da queda sofrida no ano anterior.

Em 2004, os 10 maiores importadores de carne bovina in natura do Mato Grosso do Sul eram, em ordem crescente de valor importado no ano, Rússia, Países Baixos, Itália, Reino Unido, Alemanha, Espanha, Egito, Suíça, Argélia e Hong Kong ${ }^{(12)}$. Das 127 mil toneladas de carne bovina in natura exportada pelo Mato Grosso do Sul em 2005, quase 87 mil toneladas foram destinadas a esses 10 maiores importadores, o que representou $68 \%$ do mercado exportador estadual. Com a introdução da febre aftosa no Estado em outubro de 2005, nove dos grandes importadores embargaram a carne bovina de todo o Mato Grosso do Sul, à exceção de Hong Kong. Como resultado, em 2006, as exportações desse produto caíram drasticamente: o Mato Grosso do Sul exportou pouco menos de 21 mil toneladas, $84 \%$ a menos que o ano anterior.

Do volume total exportado em 2006 pelo Mato Grosso do Sul, pouco menos de cinco mil toneladas se destinaram aos 10 maiores importadores de 2004, uma redução de $94 \%$ nas exportações para os mesmos em relação a 2005 e de $44 \%$ na participação do grupo no mercado estadual. Dessas cinco mil toneladas exportadas aos países que em 2004 eram os maiores importadores do estado, $80 \%$ destinaram-se exclusivamente a Hong $\mathrm{Kong}^{(12)}$. A Suíça foi o único país dentre os grandes importadores que não importou qualquer volume de carne bovina in natura do Mato Grosso do Sul em 2006.

Tamanha repercussão internacional culminou na acentuada queda nos preços em 2006: enquanto o ano de 2005 acumulou alta média de $141 \%$ no preço do quilograma de carne bovina exportado, em 2006 a queda foi de 83\%. Mercados importadores minoritários, que em 2005 respondiam por apenas $32 \%$ do volume de carne bovina in natura exportada pelo Mato Grosso do Sul, passaram a responder por $76 \%$ desse mesmo mercado em 2006 , comprando a carne a um valor $60 \%$ mais baixo que no ano anterior $^{(12)}$.

Em 2004, os 10 maiores importadores de carne bovina in natura do Paraná eram, em ordem crescente de valor importado no ano, Rússia, Países Baixos, Itália, Bulgária, Espanha, Alemanha, Reino Unido, Cingapura, Hong Kong e Chile ${ }^{(12)}$. Das 34,5 mil toneladas de carne bovina in natura exportada pelo Paraná em 2005, quase 25,5 mil toneladas foram destinadas a esses 10 maiores importadores, o que representou quase $74 \%$ do mercado exportador estadual. Com a introdução da febre aftosa no Estado em dezembro de 2005, exatamente como ocorrido no Mato Grosso do Sul, nove dos grandes importadores embargaram a carne bovina de todo o Paraná, à exceção de Hong Kong. Como resultado, em 2006, o Paraná exportou pouco menos de 5,5 mil toneladas, $84 \%$ a menos que o ano anterior.

Desse volume total exportado, apenas 1,5 mil toneladas se destinaram, em 2006, aos 10 maiores importadores de 2004, uma redução de 94\% nas exportações para o grupo em relação a 2005 e de $44 \%$ na participação dele no mercado estadual. Dessas 1,5 mil toneladas exportadas ao antigo grupo de grandes importadores, $56 \%$ destinaram-se exclusivamente a Hong Kong. Dentre o grupo de grandes importadores de 2004, a Bulgária, a Alemanha e o Chile não importaram qualquer volume de carne bovina in natura do Paraná em 2006 ${ }^{(12)}$. 
Diferentemente do Mato Grosso do Sul, mesmo em 2005, o Paraná já apresentava queda de 15,34\% no volume e $23,9 \%$ valor das exportações de carne bovina in natura para o mundo. Em 2006 esse cenário agravou-se para, respectivamente, $83,4 \%$ e $84 \%$ de queda no volume e valor exportados em comparação ao ano anterior. Mercados importadores minoritários que em 2005 respondiam por apenas $26 \%$ do volume de carne bovina in natura exportada pelo Paraná, passaram a responder por $73 \%$ desse mesmo mercado em 2006, comprando a carne a um valor $56 \%$ mais baixo que no ano anterior $^{(12)}$.

Assim, observou-se queda nas exportações do Mato Grosso do Sul e do Paraná, principalmente aos países que em 2004 eram os maiores importadores de carne bovina in natura. Hong Kong apareceu como um bom parceiro comercial, considerando que dentre os grandes importadores, foi o único que não estabeleceu proibição às importações de carne desses dois Estados. Em ambos os estados percebeu-se um aumento da diversificação nos destinos das exportações, frente ao forte embargo imposto pelos principais mercados importadores. Em todos os casos, a diversificação de mercados mostrou-se importante ferramenta de equilíbrio no comércio de carnes do Brasil, e estratégia para se trabalhar visando menor dependência de mercados específicos e maior segurança na continuidade das exportações.

Quando se trata da entrada de doença vesicular em área livre produtora de carne bovina, os prejuízos para os Estados são imediatos à sua confirmação: será declarado estado de emergência veterinária e proibida a saída de animais susceptíveis ou não à doença e de quaisquer outros produtos ou materiais que possam veicular o agente viral, assim como o trânsito de veículos e de pessoas não autorizadas. Ainda, a comercialização das carnes, produtos e subprodutos obtidos no abate deverá ser suspensa até definição pelo serviço veterinário oficial quanto à sua destinação ${ }^{(26)}$. A política de sacrifício sanitário é obrigatória para os casos confirmados de febre aftosa. Embora o produtor seja indenizado pelo abate do animal, tal indenização não cobre perdas com programas de melhoramento genético; nesses casos, as perdas são imensuráveis e irrecuperáveis.

As despesas do serviço veterinário oficial também são elevadas: o custo anual de febre aftosa é de aproximadamente US\$ 5 bilhões em termos de perdas com produção e vacinação. Em países com programas de controle em curso, os custos também são significativos uma vez que não há previsão de finalização do programa oficial devido aos constantes riscos de reintrodução da febre aftosa ${ }^{(11)}$. O maior trânsito de pessoas, animais e mercadorias implica no aumento de riscos de transmissão internacional dessa doença. Tal risco compromete os países na sua capacidade de exportar animais e produtos de origem animal, dificultando o acesso aos lucrativos mercados internacionais. Já os países livres de febre aftosa veem suas despesas aumentarem consideravelmente quando surtos esporádicos ocorrem e se faz necessário recuperar o status sanitário anterior. Enquanto os países livres de febre aftosa desfrutam de vantagens comerciais que este estatuto lhes traz, a manutenção do mesmo os deixa mais vulneráveis à entrada e disseminação do vírus ${ }^{(11)}$.

Estima-se que apenas uma em cada três disputas na $\mathrm{OMC}$ ganha o direito de retaliar comercialmente o Membro que não atendeu às regras previamente acordadas ${ }^{(27)}$. Resolver conflitos comerciais informalmente é muito mais eficiente, mais rápido e menos dispendioso do que entrar em uma arbitragem formal ${ }^{(28)}$. Como a febre aftosa continua a ser uma das mais importantes doenças da pecuária mundial, levando à imposição de restrições comerciais por parte dos países importadores, sua erradicação no território é a melhor forma de impedir que seja utilizada como barreira ao comércio. Frente às dificuldades em retirar barreiras sanitárias após sua imposição, o Brasil tem buscado erradicar a febre aftosa em todo o seu território a partir das diretrizes do Programa Nacional de Erradicação da Febre Aftosa (PNEFA). A meta é que até 2020 a doença esteja erradicada em toda a América do $\mathrm{Sul}^{(29)}$.

\section{Conclusões}

O surto de febre aftosa de 2005 não impediu o aumento das exportações de carne bovina in natura 
do Brasil, mas impactou negativamente as exportações dos Estados diretamente afetados pela febre aftosa: Mato Grosso do Sul e Paraná. Também não causou impacto nas exportações de carne bovina in natura do Brasil para os Estados Unidos, Japão e México, visto que tais mercados já se encontravam fechados ao Brasil antes mesmo do surto em questão. Arábia Saudita, Rússia e Irã não eram Membros da OMC em outubro de 2005 e, portanto, não tinham a obrigação de respeitar o Princípio da Regionalização, ainda que a Rússia o tenha feito. Arábia Saudita e Irã não oficializaram qualquer embargo ao Brasil. O Chile não respeitou o princípio da regionalização e a ocorrência da doença fechou aquele mercado à carne bovina brasileira in natura. Países Baixos, Egito, Itália, Reino Unido, França, Alemanha e Espanha respeitaram o Princípio da Regionalização do Acordo SPS ao definirem suas áreas de embargo às exportações brasileiras e, dessa forma, aplicaram medidas sanitárias.

\section{Agradecimentos}

Ao CNPq pelas bolsas de Produtividade em Pesquisa (PQ/CNPq) aos autores C.M. McManus e C.B. de Melo, à SDA/MAPA, SRI/MAPA e à CG VIGIAGRO/MAPA. Autorizações foram concedidas considerando-se a Nota Técnica n. 5 DNSF/SRI/MAPA/2013 de 23 de janeiro de 2013, o Processo CSG/DCA/MAPA 21000.000484/2013 - 90, de 23 de janeiro de 2013 e o Despacho da Secretaria Executiva/MAPA de 1 de fevereiro de 2013.

\section{Referências}

1. Kitching RP. A recent history of foot and mouth disease. J Comp Pathol. 1998; 118, 89-108.

2. Alexandersen S, Zhang Z, Donaldson AI, Garland AJ. The pathogenesis and diagnosis of foot-andmouth disease. J Comp Pathol. 2003; 129, 1-36.

3. Domingo E, Baranowski E, Escarmis C, Sobrino F. Foot-and-mouth disease virus. Comp Immunol Microbiol \& Infect Dis. 2002; 25, 297-308.

4. Garland AJM, de Clercq K. Cattle, sheep and pigs vaccinated against foot and mouth disease: does trade in these animals and their products present a risk of transmitting the disease? Rev. sci. tech. Off. int. Epiz. 2011; 30 (1), 189-206.

5. Scott A, Christie M, Midmore P. Impact of the 2001 foot-and-mouth disease outbreak in Britain: implications for rural studies. J Rural Stud. 2004; 20 (1), 1-14.

6. Hayama Y, Muroga N, Nishida T, Kobayashi S, Tsutsui T. Risk factors for local spread of foot-andmouth disease, 2010 epidemic in Japan. Res Vet Sc. 2012; 93 (2), 631-35.

7. IFAH - International Federation for Animal Health. The Costs of Animal Disease. Oxford Analytica, 2012. [Citado 2015 Maio 30]; Disponível em: http://www.bft-online.de/fileadmin/bft/publikationen/ IFAH_Oxford-Analytica_The-Costs-of-Animal-Disease_October2012.pdf

8. Dykes M. Agroterrorism: Minimizing the Consequences of Intentionally Introduced Foreign Animal Disease. School of Advanced Military Studies United States Army Command and General Staff College, Fort Leavenworth, Kansas AY, 2010. [Citado 2015 Maio 30]; Disponível em: file:///C:/ Users/pc/Downloads/ADA522943.pdf

9. NAO - National Audit Office. The 2001 Outbreak of Foot and Mouth Disease, Report by the Comptroller and Auditor General. The Stationery Office, London, 2002. [Citado 2015 Maio 30]; Disponível em: http://www.nao.org.uk/wp-content/uploads/2002/06/0102939es.pdf

10. Spier RE. FMD in the UK-the 2001 outbreak; what if...? Vaccine. 2001; 19(31), 4339-41.

11. OIE - Organização Mundial de Saúde Animal [Citado 2015 Maio 30]; Disponível em: www.oie. int

Cienc. anim. bras., Goiânia, v.16, n.4, p. 525-537 out./dez. 2015 
12. Brasil. Ministério da Agricultura, Pecuária e Abastecimento. AGROSTAT, 2012. [Citado 2015 Maio 30]; Disponível em: http://agrostat.agricultura.gov.br

13. ITC - International Trade Center. Trademap. [Citado 2015 Maio 30]; Disponível em: http://www. trademap.org/Product_SelProductCountry.aspx?nvpm=1|076||||TOTAL|||2|1|1|1|1\|1\|

14. Brasil. Ministério da Agricultura, Pecuária e Abastecimento. Secretaria de Relações Internacionais do Agronegócio. Restrições comerciais ao Brasil em função da ocorrência de febre aftosa nos estados do Mato Grosso do sul e Paraná em 2005. 2007b. [Citado 2015 Maio 30]; Disponível em: http:// www.agricultura.gov.br/arq_editor/file/Restricoes_Comerciais_Brasil_decorrentes_Febre_Aftosa. pdf Acesso em 02/dez/2012

15. Brasil. Ministério da Agricultura, Pecuária e Abastecimento. Programa Nacional de Erradicação da Febre Aftosa, Relatório Anual, ano base 2007. Brasília, 2008. Disponível em: http://www.agricultura. gov.br/arq editor/file/Aniamal/programa $\% 20$ nacional $\% 20$ sanidade $\% 20$ aftosa/programa $\% 20$ nacional $\% 20 \mathrm{de} \% 20$ erradicacao.pdf

16. WTO - World Trade Organization. Members and Observers. Geneva. (2013) [Citado 2015 Maio 30]; Disponível em: http://www.wto.org

17. Machado RQ. Análise do perfil das restrições comerciais à carne bovina nos acordos SPS e TBT. Dissertação de Mestrado em Economia Aplicada da Escola Superior de Agricultura Luiz de Queiroz, 2007. [Citado 2015 Setembro 10] Disponível em: http://www.teses.usp.br/teses/disponiveis/11/11132/ tde-10072007-102708/pt-br.php

18. União Europeia. Países. (2012). [Citado 2015 Maio 30]; Disponível em: http://europa.eu/abouteu/countries/index pt.htm

19. Henson S, Loader R. Barriers to agricultural exports from developing countries: the role of Sanitary and Phytosanitary requirements. World Develop. 2001; 29 (1), 85-102.

20. Brasil. Ministério da Agricultura, Pecuária e Abastecimento. Intercâmbio Comercial do Agronegócio 2007. Brasília, (2008). [Citado 2015 Maio 30]; Disponível em: http://mapas.agricultura. gov.br/agroeventos/sistema/apresentacaoEventos.asp?evento $=4$

21. Boisvert RN, Kay D, Turvey CG. Macroeconomic costs to large scale disruptions of food production: The case of foot- and-mouth disease in the United States. Econ Model. 2012; 29, 1921-30.

22. Nam K, Jo C, Lee M. Meat products and consumption culture in the East. Meat Sci. 2010; 86 (1), 95-102.

23. Brasil. Ministério da Agricultura, Pecuária e Abastecimento. Programa Nacional de Erradicação da Febre Aftosa, Relatório Anual, ano base 2008. Brasília, (2008a). [Citado 2015 Maio 30]; Disponível em: http://www.agricultura.gov.br/arq editor/file/Relatorio_PNEFA 2008 final.pdf

24. CEPEA - Centro de Estudos Avançados em Economia Aplicada. AGROMENSAL 2005 - ESALQ/ BM\&F. [Citado 2015 Maio 30]; Disponível em: http://www.cepea.esalq.usp.br/agromensal/2005/12 dezembro/Pecuaria.htm

25. CEPEA - Centro de Estudos Avançados em Economia Aplicada. AGROMENSAL 2006 - ESALQ/ BM\&F. [Citado 2015 Maio 30]; Disponível em: http://www.cepea.esalq.usp.br/agromensal/2006/12 dezembro/Pecuaria.htm

26. Brasil. Ministério da Agricultura, Pecuária e Abastecimento. Instrução Normativa $n^{0} 44$, de 02 de outubro de 2007. Programa Nacional de Erradicação e Prevenção da Febre Aftosa - PNEFA, Brasília, DF, 2007. [Citado 2015 Maio 30]; Disponível em: http://www.agricultura.gov.br/arq_editor/ file/IN $2007 \quad 44$ legislacao atual PNEFA.pdf 
27. Colares JF. The Limits of WTO Adjudication: Is Compliance the Problem? J Int Econ Law. 2011; 14 (2), 403-36.

28. Hornsby DJ. WTO effectiveness in resolving transatlantic trade-environment conflict. J Int Trade Law \& Pol. 2010; 9 (3), 297-309.

29. Panaftosa - Centro Pan-Americano de Febre Aftosa, Organização Pan-Americana de Saúde (OPAS), Organização Mundial de Saúde (OMS) [2010]. Programa Hemisférico de Erradicação da Febre Aftosa - PHEFA: Plano de Ação 2011-2020. 2010. [Citado 2015 Maio 30]; Disponível em: http://bvs1.panaftosa.org.br/local/file/textoc/PHEFA-PlanAccion-2011-2020port.pdf 